and older faculty alike. By drawing faculty away from commitment to their institutions and communities, the research culture has broken up whatever community existed within the academy and whatever connections the academy had with the public realm in the past.

The denigration of applied research and problem solving has further eroded higher education's connection to the world. The fetishism of much academic writing has contributed to the unintelligibility of academic discourse. The domination of research and publication in tenure and promotion decisions in colleges and universities that are not themselves research institutions has had a chilling effect on the faculty who do engage in the public realm. I am not advocating that faculty stop doing research and stop publishing. Far from it. But they need to do this work in settings that enable - even force- them to ask whether what they are doing contributes to the public realm. We need to ask that question again, and we need to re-create our universities to make that question central.

Note: This article is adapted from a longer article published in The Academic Workplace 10, no.1 (spring 1999): 6-11.

\title{
Student-Based Higher Education Financing Policies
}

\section{Arthur M. Hauptman}

Arthur M. Hauptman is a public policy consultant based in Arlington, Virginia, specializing in higher education finance issues. His e-mail address is <hauptman@erols.com>.

$\mathrm{P}$ olicymakers and stakeholders around the world are increasingly discussing the desirability of making public policies for higher education based more on the needs of students and less on the needs of institutions. There is considerable variation among countries in how studentbased and institution-based policies are defined. This article looks at one definition of the issue as it applies to the three major elements of financing higher education: government allocations to institutions, tuition fees, and student aid.

\section{Government Allocation Procedures}

The way in which governments allocate taxpayer funds to institutions is the principal public policy vehicle for higher education around the world. In virtually all countries, the distribution of funds to institutions is based on historical patterns, political considerations, or formulas that take into account the number of students enrolled and costs per student at different institutions. Each of these allocation policies is institution based in that the budgetary needs of institutions are uppermost in the determination. Also, very few countries differentiate among the characteristics of enrolled students in determining these allocations.

Government allocation procedures for higher education could be made more student based by factoring student characteristics into the formula for distributing funds. Thus, governments might pay institutions more for the disadvantaged students they enroll than for the more mainstream students. Another example of student-based allocation policies is for governments to pay more for students enrolling in high-priority fields than for those in other fields of study. England is perhaps the best example of a country that has moved to a student-based allocation system in which government allocations are determined more by the price the government is willing to pay for certain groups of students than by the cost of educating those students.

\section{Tuition Setting Policies}

Many higher education participants and observers would say that the fee policy most attuned to the needs of students was one in which the education was provided for free and the government picked up the whole bill. But what is missing in this formulation is that a policy of no fees benefits only the students who are enrolled. For qualified students who cannot enroll because there are not enough seats to accommodate them, a no-fees policy is distinctly not student based. A consequence of having no fees may be that the government can fund fewer spaces (because each subsidized space costs more). Put another way, a nofee policy is student based only if the government provides enough financial support to institutions to create a sufficient supply of seats to meet the demand of qualified applicants.

\section{The way in which governments allocate taxpayer funds to institutions is the prin- cipal public policy vehicle for higher education around the world.}

Most countries that charge fees now adhere at least in theory to a cost-recovery formula by which fees are set as a percentage of the educational costs per student. But like government allocation cost-recovery formulas, fees set as a percentage of costs per student are by definition institution based because they are designed to recover the cost to the institution. An example of a more student-based policy is one in which fees are set in relation to an economic indicator such as GDP per capita or median family 
income. This kind of arrangement would better accommodate the changing ability over time of students and their families to pay for higher education than would formulas based principally on institutional cost structures.

\section{Student Aid Programs}

There is a temptation to call any student aid program student based because by definition it provides aid to students. But such programs vary considerably in their structure, and some are more student based than others. In many countries, student aid takes the form of governments providing funds to institutions, which in turn select recipients from a number of qualified recipients based on criteria set by government. While this approach is certainly student based in that students receive the aid in the form of discounted prices, it is not as oriented to students as a vouchers policy in which students vote with their feet and in which the money that an institution receives is determined by how many voucher recipients enroll.

\section{Most countries that charge fees now ad- here at least in theory to a cost-recovery formula by which fees are set as a per- centage of educational costs per student.}

Another issue is what charges are covered in a student aid program and how they are paid. A program that covers only tuition fees and not other costs of attendance is less student based than one in which living costs are covered. Similarly, one could argue that the most student-based aid program would be one in which the opportunity costs of going to school rather than remaining in the workforce were covered in addition to the instructional fees and living costs. But few countries cover opportunity costs through their aid programs.

Still another way to gauge whether government policies are student based is to consider how much government funding for higher education is devoted to student aid. In many countries, this is referred to as "top-slicing"the portion of higher education funds that is set aside for student aid. Student-based policies might be those in which a relatively high proportion of total government funding for higher education - perhaps 10 percent or more-is top sliced for student aid. An institution-based approach might be one in which 5 percent or less of total higher education funding is provided in the form of student aid.

\section{But Are Student-Based Policies Better?}

The preceding discussion of government allocations, tu- ition fees, and student aid has not addressed the question, should financing policies be made more student based? My answer is yes, principally for the following two reasons: First, student-based policies are likely to be more effective in achieving the goal of access than institution-based policies. For example, a student-based fee policy that is tied to the family's ability to pay is more likely to keep fees affordable than one oriented toward financing institutional budgets. A student aid voucher program that follows the students will be more likely to produce expanded access than an institution-based aid program. Similarly, policies that allocate funds to institutions on the basis of the characteristics of students are more likely to yield results in terms of higher enrollments of targeted groups of students than allocation policies that ignore student characteristics.

Student-based policies allow governments to express their policies more explicitly than institution-based policies tied to the costs of educating students. The per student costs of education may bear little relationship to national or regional priorities. For example, if there are severe teacher shortages in a country, the fact that it costs relatively little to train teachers should not get in the way of the government paying institutions more for the teachers they produce than for graduates in some other profession. Similarly, even though the costs are typically less at rural institutions than urban ones, governments might well want to pay more for slots at rural institutions to ensure more equitable regional distributions.

Of course, no financing policy is totally institution or student based. There is a continuum along which all countries could be located. Policymakers should consider the possibility that moving toward more student-based policies will enhance the chances of improving access to higher education and meeting important national and regional priorities. This will be especially important as most countries around the world face the challenge of increasing access for traditionally underrepresented groups of students and of having higher education be more relevant to their societies at a time when resources are unlikely to grow sufficiently to keep up with exploding demand.

\section{Centers and Institutes: We Still Need Your Help}

We are currently completing work on our inventory of centers and institutes in the field of higher education worldwide. The inventory will feature full information about policy centers, research institutes, academic programs, and other organizations focusing on higher education. We will publish the inventory as a book and also make it available on the WWW. If you are associated with a relevant organization that has not responded to our questionnaire, please contact us immediately, and we will provide information to you. Please contact Dave Engberg at <highered@bc.edu>. 